\title{
Practice and Exploration of Huangmei Opera Art Education in Local Colleges and Universities Taking Huanggang Normal University as an Example
}

\author{
Sha $\mathrm{Tao}^{1, *}$ \\ ${ }^{1}$ College of Fine Arts, Huanggang Normal University, Huanggang, Hubei, China \\ *Corresponding author. Email: 397121395@qq.com
}

\begin{abstract}
Huangmei opera is one of the five major dramas in China. It originated in Huangmei County of Huanggang City and is loved by the masses. As the only local university in the local area, Huanggang Normal University has attached great importance to Huangmei opera art education in recent years. The school has adopted a series of measures, and has combined the school development with local characteristics, talent training with professional construction, artistic practice with inheritance and innovation, and art education with scientific research, making contributions to the development of opera art education and the inheritance of traditional Chinese culture in local colleges and universities.
\end{abstract}

Keywords: local colleges and universities, Huangmei opera, art education

\section{INTRODUCTION}

Huangmei opera is one of the five major dramas in China. It originated in Huangmei County of Huanggang City with a simple and natural style and is loved by the masses. Since the Hubei Provincial Party Committee and Provincial Government decided in 1989 to "invite Huangmei opera to its mother's home", Huangmei opera has achieved brilliant results in Huanggang and has created a large number of excellent plays, and a large number of outstanding talents have emerged. Since 2009, Huanggang Normal University, as the only local college in Huanggang, has attaches great importance to the art education of Huangmei opera and has taken a series of measures to make a great contribution to the inheritance and development of Huangmei opera.

\section{COMBINING SCHOOL DEVELOPMENT}

\section{WITH LOCAL CHARACTERISTICS}

In 2009, the Hubei Provincial Humanities and Social Sciences Key Research Base — "Huangmei Opera Art Research Center" was officially established at the school. In 2016, the school held the listing ceremony of School of Huangmei Opera at Huangmei Opera Theater in Hubei Province. From then on, the Conservatory of Music was officially renamed as the

*Fund: This paper is the final research result of the 2017 Huangmei Opera Art Research Center Project of Hubei Province Ordinary Colleges and Universities Humanities and Social Sciences Key Research Base "Practice and Exploration of Huangmei Opera Art into Colleges and Universities Education" (Project No. 201712203).
School of Music, Drama and Huangmei Opera, and implemented the management and operation mode of "two brands and a set of teams". The School of Music, Drama and Huangmei Opera makes full use of the school's existing faculty and school resources, and cooperate in depth with the Hubei Huangmei Opera Theater to explore the high-level Huangmei opera talent training model using its creation and performance platforms. In 2016, the Music Education major of the Conservatory of Music set up the major direction of Huangmei opera and began to recruit students. In 2017, the School of Music and Drama enrolled the Drama and Film Performance major and established the direction of Huangmei opera.

The School of Music, Drama and Huangmei Opera combined with the actual needs of Huangmei opera's social development, established the three research directions of Huangmei opera's repertoire and origin, Huangmei opera's vocal tract and its development, and Huangmei opera performance. It has reached in-depth cooperation with Huangmei opera theaters and troupes in Hubei Province. So far, 99 in-service actors have been trained for troupes and 30 performance talents of Huangmei opera have been trained in counties and cities of Huanggang. It conducts a series of activities such as the Huangmei opera elective course, Huangmei opera knowledge lecture, the establishment of the Huangmei Opera Society and the Huangmei Opera Student Association, and interscholastic Huangmei opera exhibitions and so on, so as to conduct study and research of Huangmei opera. 
After years of hard work, the school has now formed a relatively complete professional and amateur Huangmei opera art education system, which is conducive to combining the development of the school with local characteristics and improving the level and standard of school operation.

\section{COMBINING TALENT TRAINING WITH PROFESSIONAL CONSTRUCTION}

The cultivation of Huangmei opera artistic talents at Huanggang Normal University aims at bringing up versatile talents with a combination of theory and practice and a wider range of adaptability to enable students to become a compound all-rounder who not only understands professional knowledge and takes a firm stand on the platform, but also inherits and innovates and spreads opera culture. In order to strive to achieve the above goals, the school solidly carries out talent training work, specifically as follows:

\section{A. Holding various seminars on Huangmei opera}

The school has held large-scale Huangmei Opera Academic Seminars, Huangmei Opera Art Seminars, Huangmei Opera Music Seminars. The school invited Zheng Chuanyin, Zhu Hengfu, Chen Jinggeng, Yang Jun, Zhang Hui and a large number of Huangmei opera performance artists, opera research scholars, experts and scholars from key disciplines inside and outside Hubei Province to come to the Conservatory of Music to give lectures for teachers and students there, in order to expand the teachers and students' horizons of the school and improve their scientific research level, performance level and creative level of Huangmei opera.

\section{B. Holding on-campus Huangmei opera training class}

In order to strengthen the drama and film science discipline and Huangmei opera professional construction, based on the introduction of drama teachers and the training of existing teachers, the school held a training class for the winter vacation of Huangmei opera in early 2018. Pan Wenge, dean of the Performance Department of Anhui Huangmei Opera Art Vocational College, and Hu Jizong, vice director, carried out systematic counseling for more than 40 teachers and students of the School of Music, Drama and Huangmei Opera around Huangmei opera singing tune and body performance. In July of the same year, the school also held a summer training class for Huangmei opera, and invited experts from Anhui Huangmei Opera Art Vocational College to assist Huangmei opera singing tune and performance. 30 teachers and students from the School of Music, Drama and Huangmei Opera participated in the training.

\section{Organizing students to participate in various teaching and competition performances}

In 2011, the Huangmei opera playlet "Zi Jiao Qing" created and performed by students of the school won the first prize of the literary and artistic program of the "Fourth College Students Art Festival" of the Education Department of Hubei Province; in 2012, student Zhou Jiajie won the third prize in the Hubei Art Festival undergraduate drama competition for singing "Drunkened Concubine — the Island Moon Just Started to Twirl", and she also won the second prize for singing "Flower Duet" in the Fifth College Student Art Festival in Hubei Province in 2014; in 2016, Gu Cheng, Bu Fan and other 8 students performed the Huangmei opera playlet "Couple View of Lights". They sang and danced in a lively and novel way, endowing the traditional Huangmei opera with a new interpretation and won the Hubei Provincial Drama into Campus Exhibition Competition Performance Excellence Award. Zhu Yaping won the Excellent Performance Award in the "Blockbuster - Huangmei Opera Famous Masters and Tickets Group Tournament" column of CCTV Drama Channel; in 2019, student Zhu Hongyan was invited to participate in a live performance at the Hubei University Drama Exhibition held at the South-Central University for Nationalities on November 19. Her performance of "Huangmei Opera Traditional Coloratura Mixed Singing" showed the spirit of contemporary college students who loved traditional art and were brave in stage innovation, and won the title of "Campus Drama Star". In 2019, the school held a special report-back performance of Huangmei opera of Pan Meijing's students from 2017 class, including Huangmei opera selections of "Sending Scented Tea", "In the End There Is More Joy in the World", "Goddess Marriage - Magpie Bridge", and "Sister Jiang Spring Silkworm Still Produce Silk to Death" and so on, as well as Huangmei song "Wind in the Mountains" and drama and dance — "Water of Honghu Lake, Waves Hitting Waves". The performances and singing by the students fully demonstrates the contemporary college students' enthusiasm for Huangmei opera, a precious cultural heritage. At the same time, it also reflects the level of training talents for Huangmei opera performers in the school.

\section{COMBINING ART PRACTICE WITH INHERITANCE AND INNOVATION}

The Huangmei opera art education at Huanggang Normal University aims to train higher-level opera talents to expand the troupe of opera performance, creation and dissemination, to promote the dissemination and popularization of local opera in the surrounding areas and even the whole country, to promote traditional Chinese culture and to improve the artistic quality of the people. 


\section{A. Actively organizing teachers and students to participate in art practice}

In 2011 and 2012, students participated in the creation and performance of "Li Suguang" and "Su Tungpo" in the Huanggang celebrity series of largescale Huangmei operas with local characteristics in the Huangmei Theater of Hubei Province, which were performed at the National Centre for the Performing Arts, Chang'an Grand Theater and the Central Party School and were widely praised.

In 2018, a large-scale red Huangmei opera "Mother of Dabie Mountain" produced by the school and Hubei Province Huangmei Opera Theater, which can be said to be a literary and artistic revolution historical theme produced by the school-region cooperation, was selected for the outstanding performance of the 8th China (Anqing) Huangmei Opera Art Festival. This opera was performed 3 times respectively in the evening of October 1st, the afternoon of the 2nd, and the evening of the 3rd in the Huangmei Opera Art Center of Anqing City. The opera was planned by professor Duan Youfang and secretary Yu Yaguang of the school, composed by teacher Ding Yonggang, choreographed by teacher Xu Min, and participated by more than ten students. In terms of music, Ding Yonggang not only drew on the folk songs of Dabie Mountain, but also boldly used some classic arias and blended them into the tunes of Huangmei opera, making the music of the opera have the characteristic of "Huangmei opera of Hubei School". The choreography of teacher $\mathrm{Xu}$ Min is largely integrated into the local conditions and customs of the old revolutionary base of Huanggang, which is a brand-new attempt of Huangmei opera to inherit innovation and artistic exploration.

At the end of 2019, the school's large-scale original Huangmei opera "A Red Candle in Frosty Days" was successfully audited in the school concert hall. The drama was screened by Hou Lu, a specially-appointed professor of the school and a national first-class screenwriter; the school's specially-appointed professor and the winner of Chinese drama "Plum Blossom Award", Zhang Hui, served as the director; the school's professor Duan Youfang served as an associate director and project leader; teacher Ding Yonggang composed; teacher Pan Ningjing played the part of "Huang Shilan"; the national second-level actor Wang Gang played the part of "Luo Peigang"; Zhao Hua, Lu Kunpeng, Li Jingxian, Wang Haiyan, Wang Haotian and more than 80 teachers and students participated in the show. "A Red Candle in Frosty Days" takes the school's red history as the creative background, takes the century-old school's "not forgetting the original heart and being willing to stand fast" as the theme, takes the Huangmei opera music drama as the form, and tells the touching story of the teacher group represented by Huang Shilan who was not afraid of sacrificing and insisting on running the school during the revolutionary war, "a teaching pointer accompanying whole life long" and "passing down from generation to generation, and difficulty being the nurse of greatness".

In 2020, the school and Huangmei Theater of Hubei Province and Hubei Drama Art Theater jointly produced the Huangmei opera song "White Coat Winning Snow". This Huangmei opera song was produced by Mr. Bai Lin, a leader of Huangmei opera music; Xu Liexing, the alumnus of the school and vice chairman of the Huanggang City Literary Federation, wrote the song; Ding Yonggang, an associate professor and young composer of the school, composed; the famous Huangmei opera performing artists Yang Jun and Zhang Hui sang. This opera song pays tribute to the "angel in white" with traditional opera music, and pays respects to the majority of medical workers.

\section{B. Actively carrying out a series of activities of "traditional opera into campus"}

To begin with, it established Huangmei Drama Club in colleges and universities: in July 2017, the school established Huangmei Drama Club, and Duan Youfang, the dean of the School of Music, Drama and Huangmei Opera, served as the proprieter of Huangmei Drama Club; Zhang Hui, Huangmei opera performing artist and national first-class actor, served as art director. This club strictly abides by the regulations, conscientiously performs its duties, enriches the activity carrier, pays attention to personnel training, promotes the inheritance of art, and actively takes the responsibility of polishing the cultural card of Huanggang City, becoming an important position for teenagers to popularize opera knowledge and inherit opera art. In addition, it held various special performances of Huangmei opera. In 2018, the school held a special performance of Huangmei opera — "Huanggang Normal University Celebrating the 40th Anniversary of Reform and Opening-up Policy". The performance kicked off in the Huangmei opera "Goddess Marriage - Magpie Bridge" performed by teachers of the School of Music, Drama and Huangmei Opera. The performance was brilliant, not only bringing cheers and laughter to everyone, but also letting the teachers and students of the school realize the charm of Huangmei opera. In December of the same year, the school held a special evening party of Huangmei opera in Huangmei Opera Theater. In this party, the teachers and students of the school performed shows such as "Goddess Marriage Magpie Bridge", "The Zhaojun Out of the Frontier Fortress ", "In the End There Is More Joy in the World", "Out of the Daze and Then into the Daze", "The Brilliant Scenery of Huangzhou", "For Whom Is the Moon Round in Fifteen", "Flower Duet", "Wind in the Mountains", "Goddess Marriage — Road Meeting", "Goddess Marriage - Couples Return Home", the drama and gun pose combination and Huangmei Opera 
Coloratura Mixed Singing and so on, which have received unanimous praise from teachers and students of the school and Huanggang City fans. What's more, it carried out a series of activities such as holding interschool Huangmei opera exhibitions and lectures on Huangmei opera knowledge to carry out learning, research and inheritance of Huangmei opera. The school invited Zhang Hui, Yang Jun and other Huangmei opera performing artists to give lectures on Huangmei opera performing arts; at the same time, it also invited Professor Zheng Chuanyin, a doctoral tutor of Wuhan University, Mr. Yang Pulao, a senior artist of Huangmei Theatre Troupe, and Professor Zhu Hengfu, a doctoral tutor of Shanghai University, Professor Li Wei of Shanghai Theatre Academy, national first-level composer Chen Jinggeng, and national first-class actor visiting professor Pan Wenge, etc. to give special lectures on the form of Chinese opera, the development history and artistic characteristics of Huangmei opera, and Huangmei opera performance and so on.

\section{Actively carrying out activities of sending literature and art to the countryside}

The school often relies on the School of Music, Drama and Huangmei Opera to organize "sending literature and art to the countryside" activities. It has carried out public performances in Macheng, Tuanfeng, Luotian, Huangmei and other villages and towns, as well as primary and secondary schools, and performed Huangmei operas such as "Coloratura Mixed Singing" and "Couple View of Lights", "Couples Return Home" and other classic pieces. The school sends the drama to the countryside through social welfare practice activities. Every place the show went to was warmly welcomed by the local people, satisfying the expectations and desires of the people in the old district of Dabie Mountain to appreciate the local traditional opera art.

\section{COMBINING ART EDUCATION WITH SCIENTIFIC RESEARCH}

In 2009, Huanggang Normal University established the Hubei Provincial Humanities and Social Sciences Key Research Base - "Huangmei Opera Art Research Center" to promote the development of Huangmei opera art education with relevant scientific research results.

\section{A. Establishing a strong research team to focus on solving the academic problems of Huangmei opera}

Huangmei Opera Art Research Center brings together a group of academic backbones with high quality and strong capabilities. The center currently has 34 scientific researchers, including 4 professors, 4 national first-level actors, first-level screenwriters and first-level composers, 10 associate professors, and 4 second-level actors, second-level screenwriters and second-level composers. The team has a strong sense of innovation, and has obtained more than 100 projects of various types at various levels, with a funding of more than 2 million yuan. These include the "Training Class for Huangmei Opera Actors" of the Intangible Cultural Heritage Inheritance Project of the Ministry of Human Resources and Social Security, the Ministry of Culture and the Ministry of Education, Ministry of Education Planning Fund Project "Research on Huangmei Opera in the New Period", Research Project of Cultural Arts of the Ministry of Culture "Research on Hubei Huangmei Opera in the New Period", and more than 20 provincial and departmental projects. It produced a number of influential and iconic research results, including 7 monographs such as "Consolidating the Foundation and Innovating - On the Modernization Exploration of Huangmei Opera in the New Period" and "On Huangmei Opera Art". Researchers of the center published 223 papers in professional journals such as "Art of Opera", "Study of Traditional Opera", "Jianghuai Forum" and "Sichuan Drama", and a strong atmosphere of Huangmei opera research was formed throughout the school.

\section{B. Applying scientific research results to teacher training and teaching}

Firstly, it recruits in-service actors from various troupes for further training, so as to further improve the performance level and theoretical level. From 2018 to 2019, the school relied on the Intangible Cultural Heritage Inheritance Project of the Ministry of Human Resources and Social Security, the Ministry of Culture and the Ministry of Education - "China Intangible Cultural Heritage Inheritance Group Training and Training Program - Training Class for Huangmei Opera Actors" to carry out two consecutive trainings of Huangmei opera actors. 99 professional artists and practitioners from the Huangmei Theater of Hubei Province, Yingshan County Huangmei Theater Troupe, Huangmei New Image Culture and Art Troupe and private Huangmei Theater Group participated in the training. The training invited Academy of Traditional Chinese Opera, Huangmei Theater of Hubei Province, Hubei Local Drama Art Theater, famous drama research experts from Anqing Normal University, intangible cultural heritage scholars, Huangmei opera performance artists, national first-class actors, and highlevel professors from Huanggang Normal University to provide professional guidance to the trainees from the aspects of professional theoretical courses, practical courses, basic courses, promotion courses, practical activities, etc., so as to cultivate students' professional ability, professional ability and adaptability in an allround way, further improve their theoretical level, singing level and performance level, and vigorously promote the construction of the intangible cultural 
heritage talent team of Huangmei opera and the sustainable development of Hubei local opera. Secondly, it sets up a special class of Huangmei opera in the School of Music, Drama and Huangmei Opera to train talents for Huangmei opera performers and make Huangmei opera have qualified successors. Thirdly, it insists on scientific research to serve teaching, and has set up a compulsory course "Huangmei Opera Singing and Appreciation". In 2016, this course was successfully selected as a provincial-level excellent course. Students also actively participate in the research of Huangmei opera, not only learning the classics of Huangmei opera in elective courses, but also choosing the research direction of Huangmei opera in course papers and graduation thesis.

\section{Conclusion}

Huanggang Normal University's Huangmei opera art education has not started for a long time, but it has accurate goals and effective implementation. Therefore, it has achieved certain results in a relatively short period of time. Aiming at the problem of how local universities with rich opera heritage use local resources to carry out art education, Huanggang Normal University's Huangmei opera art education practice has made a very useful exploration.

\section{References}

[1] Chen Ming, Lu Xiaozhou. Feasibility study of Huangmei opera teaching in Hubei and Anhui universities [J]. Grand Stage, 2014(03):207-208. (in Chinese)

[2] Wang Ping. Exploration and practice of opera art education in local colleges and universities - Taking Huangmei opera art education in Anqing Normal University as an example[J]. Journal of Anqing Normal University (Social Science Edition), 2011,30(04):101-103. (in Chinese)

[3] Dai Xianying. Cultural construction of art vocational college Taking Anhui Huangmei Opera Art Vocational College as an example [J]. Theory of Learning, 2012(27):162-163. (in Chinese)

[4] Liu Yan. Development of Huangmei opera in Hubei Province and countermeasures $[\mathrm{J}]$. Journal of Huanggang Normal University, 2019, 39(04): 64-66. (in Chinese)

[5] Duan Youfang. A brief discussion on Huangmei opera art research project construction [J]. Journal of Huanggang Normal University, 2010, 30(01): 32-35. (in Chinese)

[6] Jiang Diming. Peaches and plums do not talk, yet a path is formed beneath them - Talking about starring in "cuckoo red from year to year" [J]. Huangmei Opera Art, 2017.12. (in Chinese) 